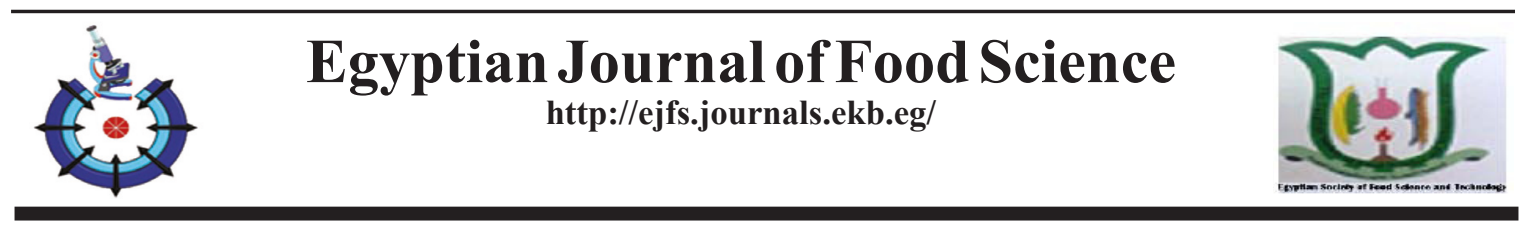

\title{
Producing Stuffed Pate and Potatoes Buriet with Kareish Cheese Fortified with Functional Foods
}

\author{
Mohamed Nour-Eldin Farid Hamad ${ }^{1 *}$, Dina Hamed El-Bushuty ${ }^{2}$ and \\ Hajar S. El-Zakzouk ${ }^{3}$ \\ ${ }^{1}$ Dairy Department, Faculty of Agriculture, Damietta University, Egypt. \\ ${ }^{2}$ Home Economics Department, Faculty of Specific Education, Damietta University, \\ Egypt. \\ ${ }^{3}$ Dairy Department, Faculty of Agriculture, Damietta University, Egypt.
}

\begin{abstract}
$\mathrm{N}$ attempted to produce the stuffed pate and potatoes buriet with kareish cheese fortified with $1 \%(\mathrm{~W} / \mathrm{W})$ oat, talbina, lima bean and sweet lupin. The portion size of control and fortified kareish cheeses added at $15 \%(\mathrm{~W} / \mathrm{W})$. In addition, determination the organoleptic evaluation and calculating of total calories of stuffed pate and potatoes buriet with fortified kareish cheese with functional foods at fresh. Results indicated the differences in the nutritional values that appeared on kareish cheese as a result of fortifying it with functional foods. The more increase in concentration of fortification, the more increase in nutritional values of kareish cheese which appeared in the chemical composition including (moisture, protein, fat, fiber, ash, $\mathrm{Mg}, \mathrm{K}, \mathrm{Fe}$, $\mathrm{Zn}$ ) contents. Furthermore, sensory evaluation was carried out and the results presented that pate and potatoes buriet which added to them about $15 \%$ of control kareish cheese was the highest acceptance, followed by those added to them kareish cheese fortified with talbina, lima bean, oat and sweet lupin, respectively. Moreover, total calories were calculated for the fresh treatments of kareish cheese which were included in producing pate and potatoes buriet products (Kcals/15 g). It was found that pate and potatoes buriet which added to them about $15 \%$ of kareish cheese fortified with sweet lupin were the highest calories, followed by the kareish cheese control, the kareish cheese fortified with talbina, lima bean and oat, respectively.
\end{abstract}

Keywords: Oat; Talbina; Lima bean; Sweet Lupin; Organoleptic evaluation; Total calories

\section{Introduction}

Kareish cheese is considered one of the most popular local types of fresh soft cheeses in Egypt. It is characterized mainly by its low-fat content and acidity. Kareish cheese is one of the best non-meat sources of protein and its high contents of vitamins and minerals such as $\mathrm{Fe}, \mathrm{Ca}$ and $\mathrm{Zn}$ that help protecting bones, body, and health. Given the growing awareness of the health of the consumer, Kareish cheese becomes very popular as its remarkable health quality as the only known fat free cheese relatively consumed by the Egyptians. It is often recommended for persons who are suffering from obesity, cholesterol, and heart disease (Effat et al., 2001; Ghada et al., 2004; Osman et al., 2010 and Fayed et al.,
2014). Oats, Avena sativa L., belongs to the genus Avena. Oat used as a functional food in some dairy products such as milk beverage, yoghurt, soft cheese, biscuit, cookies, and Spaghetti (Weightman et al., 2004; Swapna \& Rao, 2016 and Xue et al., 2019). Barley, Hordeum vulgare L., belongs to the Gramineae family. Islam had defined barley water (Talbina), which is defined as a special diet made from fresh barley grains. The description of talbina in Sunah and Hadith might show its benefits in the prevention of many diseases such as asthma, allergies hypertension and obesity (Jensen et al., 2006). Bawazir (2012) mentioned that, the preparation of the barley water (Al-Talbina) was as follows: soup made by of two tablespoons of crushed barley grains, then adding to them a glass of water, after that

Corresponding author: E-mail: dr_mnour@du.edu.eg,mnour20002005@gmail.com, Tel.+201004855145,

Scopus Author ID: 57194782076, ORCID: http://orcid.org/0000-0003-4423-0396

Received: 23/6/2020; accepted: 4/10/2020

DOI: $10.21608 /$ ejfs.2020.33606.1064

C2020 National Information and Documentation Centre (NIDOC) 
cooked over low heat for $5 \mathrm{~min}$. Talbina used in some dairy products such as yoghurt as reported by Hathout and Aly (2010). Sweet lupin, Lupinus albus L, belongs to the Fabaceae family. Sweet lupins have minimal amounts of bitter alkaloids, at levels of $<200 \mathrm{mg} / \mathrm{kg}$ according to Australian Food Standards, found in many traditional crops (Kouris-Blazos and Belski, 2016). Lupin flours, protein concentrates, and isolates can be applied as a substance in order to enrich different kinds of food systems such as bakery products, ice cream, Yoghurt, kareish cheese, cheddar cheese, soft cheese and Ras cheese (Christian et al., 1999; ElNemr et al., 2007; Snowden et al., 2007; Eisner et al., 2008; Kohajdova et al., 2011; Awad et al., 2014 and Elsamani et al., 2014). Lima bean, Phaseolus lunatus L., belongs to the leguminosae family and is predominately cultivated in South America. Lima beans are rich in protein and have appreciable functional properties such as foaming capacity, solubility capacity, bulk density, swelling index, water absorption capacity and emulsion capacity that could be exploited in food formulations as Koose, stews and sauces (Yellavila et al. 2015). This study was planned to produce stuffed pate and potatoes buriet with kareish cheese fortified with $1 \%$ oat, talbina, lima bean and sweet lupin. Moreover, determination of the sensory evaluation and calculating of the total calories for the resulting products.

\section{Material and Methods}

\section{Materials}

Skim milk powder (SMP) being used was obtained from local market called "El-Sherbiny" in Damietta Governorate, Egypt.Starter culture was freeze-dried culture DVS of mesophilic bacteria called commercially "Dairy40" obtained from (Ch. Hansen's Lab A/S Copenhagen, Denmark) and kept under suitable conditions until use.Functional foods:Oat flakes, Lima beans, and white lupins (sweet lupin) were boughten from "Harraz" company, Cairo, Egypt. Grounded Barley "Talbina" was purchased from "ElSherbiny" market in Damietta, Egypt.Commercial clean good grade of cooking salt $(\mathrm{NaCl})$ was obtained from "El-Khair»SECOSALT company, Egypt.Kareish cheese mats»Shenda» which made of «Reed» and White Cheese Cotton Clothwere bought from local market, Damietta, Egypt.

\section{Methods}

\section{Preparing of functional foods}

Oat (Avena sativa L.) flakes were ground into powdered form in (High Speed Multi-funcition
Grinder/25000rpm/min/China) Machine. Talbina (Hordeum vulgare L.) was brought from market and used asis it without any preparations. Sweet Lupin powder (Lupinus albus L.) was carried out as described by (Levent and Bilgi Çli, 2011). Sweet lupin contains bitterness compounds such as tannins which are disposed of by heat treatments at $60-70^{\circ} \mathrm{C}$ for $90 \mathrm{~min}$ in tap water and subsequent soaking for four days considering that soaking wateris refreshed four or five times during the soaking period in order to removing alkaloids, this process namely "Debittering Process" (Yorgancilar et al., 2009). Seeds were dried in an oven at $50^{\circ} \mathrm{C}$ for $10 \mathrm{hr}$, then dried lupin seeds and ground in a mill (High Speed Multi-funcition Grinder/ China) such as wholegrain powder. Mature Lima Bean seeds (Phaseolus lunatus L.) were prepared according to the method described by Hassan and Bello, (1988). The "perfect and healthy" seeds were soaked in water for six hours to make easy the disposing of tannins components. Many soaked grains were self-hulled during soaking in water but the remaining grains which were not hulled in soaking water were peeled manually then the hulled seeds cotyledon were dried in the oven at $55-60^{\circ} \mathrm{C} / 24 \mathrm{hr}$. After drying, the dried cotyledons were ground into powder into (High Speed Multi-funcition Grinder machine/China); the grind lima beans were sieved through a $1 \mathrm{~mm}$ test sieve.

\section{Manufacture of kareish cheese}

Kareish cheese was made according to the method adopted by Effat et al. (2001) with some modifications. Kareish cheese was manufactured using skim milk powder reconstituted in $10 \%$ water. The reconstituted skim milk powder was divided into five equal portions, one as a control and four portions fortified with concentrations $1 \%$ of different functional foods used as follows: $10 \%$ reconstituted skim milk powder was pasteurized at $84 \pm 2^{\circ} \mathrm{C} / 2 \mathrm{~min}$, cooled to $32 \pm 2^{\circ} \mathrm{C}$, kept in the refrigerator at $102 \pm^{\circ} \mathrm{C}$ for $6 \mathrm{hr}$ to facilitate the process of protein melting with hydrous reconstitution, inoculated with $3 \%$ freshly activated mesophilic bacterial starter culture and incubated at $43 \pm 2^{\circ} \mathrm{C}$ up to curdling. After complete coagulation, the curd was kept in refrigerator at $102 \pm^{\circ} \mathrm{C}$ from $2-3 \mathrm{hr}$ to help hold the curd more to facilitate the curd ladle process and kept the moisture inside for high yield ratio. The curd was cut and ladled in white cheese cotton cloth which was put into kareish mat as in traditional method and dry salted $2.5 \% \mathrm{NaCl}(\mathrm{W} / \mathrm{V})$ and divided to five portions as follow: (1) Control (C) without

Egypt. J. Food Sci. 48, No. 2 (2020) 
any additives; (2) added $1 \%$ oat powder to curd (W/W); (3) added 1\% grounded Barley «Talbina» to curd(W/W); (4) added 1\% mature Lima Bean seeds powder to curd (W/W) and (5) added 1\% sweet Lupin powder to curd (W/W). The mat was left for whey draining all night. Kareish cheese was taken out and weighted to calculate cheese yield. Cheese samples were collected at zero time (fresh).

\section{Chemical analysis}

Moisture content was determined as described by AOAC (2012). Fat content for reconstituted SMP was determined by using the conventional Gerber's method. On the other hand, the fat content for kareish cheese treatments and the functional foods powder was measured using Soxhlet Apparatus as described by AOAC (2012). Total nitrogen content was determined by the semi-micro kjeldahl method as described by AOAC (2012). To calculate the protein content ( $\mathrm{P} \%$ ), the nitrogen content was multiplied with a sample-specific protein factor (6.25). Ash content for functional foods powder, SMP and kareish cheese samples was measured according to AOAC (2012).Crude fiber content of the functional foods powder and their fortified kareish cheese treatments were estimated according to the method described by AOAC (2012).

Minerals content:

Iron $(\mathrm{Fe})$, zinc $(\mathrm{Zn})$ and Magnesium $(\mathrm{Mg})$ were determined using Atomic Absorption Spectrophotometer (Pectin-Elmer, PinAAcle ${ }^{\mathrm{TM}}$ 500 AA) according to (APHA, 2005). Potassium (K) was determined using flame photometer according to Hesse and Hesse (1971).

Carbohydrates content were calculated by difference from the following equation:

$\%$ Carbohydrates content $=100-(\%$ protein $+\%$ moisture $+\%$ ash $+\%$ fats $+\%$ fibers $)$.

Total calories were calculated by using the equation mentioned by Livesey (1995), while the caloric value was calculated using values of $4 \mathrm{Kcal} / \mathrm{g}$ for carbohydrate, protein, and $9 \mathrm{Kcal} / \mathrm{g}$ for fat.

Sensory evaluation of fortified kareish cheese samples were carried out according to ElShafei et al. (2008) with some modification. The samples were presented to the panelists of the staff members of the dairy science department, faculty of agriculture, Damietta University. Panelists evaluated cheese for appearance and color (5points), body and texture (5 points) and flavor (10points). On the other side, the sensory evaluation of treatments of products made with fortified kareish cheese in fresh condition was assessed according to Watts et al. (1989) with some modification. Samples were evaluated for color (10 points), taste (40 points), odor (10 points), texture (20 points) and Overall acceptability (20 points) to be 100 points for the total scores.

\section{Preparation of products}

Preparation of pate stuffed with control and fortified kareish cheese

The method was determined according to Gassenmeier and Schieberle (1994) with some modifications. Wheat powder $(500 \mathrm{~g})$, cow butter $(200 \mathrm{~g})$, egg $(50 \mathrm{~g})$, whole milk $(300 \mathrm{ml}), 3$ tbsp sugar (42.53g) and 1 tsp salt $(4.73 \mathrm{~g})$ were made up to a dough in mixer, put in the refrigerator at $10 \pm 2^{\circ} \mathrm{C}$ for $15 \mathrm{~min}$. After that the dough was rolled out to a layer and then covered with melted butter $(250 \mathrm{~g})$, the dough was given two half turns to three and it could rest in the refrigerator for $20 \mathrm{~min}$, then procedure was repeated twice. At the end rolling the dough out to a layer with an equal thickness $(3 \mathrm{~mm})$ then cutting out. Putting the required portion weight of control/fortified kareish cheeses $(15 \mathrm{~g})$ on $100 \mathrm{~g}$ of rolled out dough for every treatment separately then rolled with the portion of cheese and baked at $180^{\circ} \mathrm{C}$ for $20 \mathrm{~min}$ in oven (the addition at rate of $15 \%$ from product weight).

Preparation of potatoes buriet with control and fortified kareish cheese:Potatoes washed well with tap water, then the boiling water was added, and a continuous stirring $5 \mathrm{~min}$, peeling the boiled potatoes. After that, puree $300 \mathrm{~g}$ of boiled potatoes with $30 \mathrm{~g}$ of cow butter, $10 \mathrm{~mL}$ whole cow milk, some spices such as salt, dried cumin and Coriander and parsley leaves for decoration. Adding the required portion weight of control/ fortified kareish cheeses $(45 \mathrm{~g})$ to $300 \mathrm{~g}$ of potatoes buriet for every treatment separately (the addition at rate of $15 \%$ from product weight).

Statistical analysis of all experimental data was done using the statistical software package of CoStat (2005).

\section{Results and Discussion}

In a previous study, it became clear that the best addition percentage to fortify kareish cheese with functional foods such as oat powder, talbina powder, lima bean powder and sweet lupin powder are $1 \%$, which clarified that the addition rate of $1 \%$ for all functional foods was more acceptable in the sensory evaluation, we

Egypt. J. Food Sci. 48, No. 2 (2020) 
had been manufacturing pate and potatoes buriet with kareish cheese (control) and fortified kareish cheeses from this more acceptable this ratio. For some reasons worth mentioning below: (1) In order to raise the consumer acceptance and demands of the fortified kareish chesses. (2) As a form of increasing consumer marketing for the control and fortified kareish cheeses with functional foods among many groups in society. (3) For the high nutritional values of kareish cheese which resulted in fortifying it with functional foods which presented its great effects in chemical composition, antioxidant activities and anti-microbial roles.

Nutritional value of fresh kareish cheese and kareish cheese with fortified of functional foods

From data tabulated in Table 1, the moisture content recorded the highest value $(76.262 \%)$ in kareish cheese with $1 \%$ oat flours. The highest protein, fat, fiber content values at 18.412, 1.780 and $0.083 \%$, which were followed by kareish cheese with $1 \%$ sweet lupin flour. While cheese with $1 \%$ talbina powder presented the highest ash value at $2.210 \%$. The highest fiber content was in kareish cheese with $1 \%$ sweet lupin flour (0.083). Furthermore, kareish cheese with $1 \%$ oat flours recorded the highest ash values at 2.26. Besides, control treatment presented the lowest $\mathrm{Mg}, \mathrm{K}, \mathrm{Fe}$ and $\mathrm{Zn}$ content at values of 82.00, 1147.40, 8.21 and $5.35(\mathrm{mg} / 100 \mathrm{~g})$, respectively. When cheese with $1 \%$ sweet lupin flour achieved the highest $\mathrm{Mg}$ and $\mathrm{Zn}$ contents at values of 117.00 and7.070, respectively. Also, cheese with $1 \%$ lima bean flour achieved the highest $\mathrm{K}$ content at value of
1252.03. Additionally, cheese with $1 \%$ oat flours obtained the highest iron content at value of 10.52.

Calculation of the total calories for the fresh samples of kareish chesses

The total calories for the fresh samples of control and fortified kareish chesses stuffed in pate and potatoes buriet products. The portion size of all control and fortified kareish cheeses added at rate of $15 \%(\mathrm{~W} / \mathrm{W})$. Indeed, kareish cheese with $1 \%$ sweet lupin flour treatment recorded the highest total calories at energy, 15.22 (Kcals/15g). Followed by control Kareish cheese treatment which achieved total energy, 15.00(Kcals/15g). Then kareish cheese with $2 \%$ talbina powder treatment with total energy, 14.57 (Kcals/15g). After that, kareish cheese with 1\% lima bean flour treatment which determined energy, 14.05 (Kcals/15g). While kareish cheese with $1 \%$ oat flour treatment occupied the last rank at total energy, 13.86 (Kcals/15g) (Table 2).

Pate stuffed with control and fortified kareish cheeses in ratio of $1 \%$ lima bean, sweet lupin, oat and talbina

\section{1- Sensory evaluation}

The average opinion values of the ten panelists and judges were summarized in Fig. 1. Obviously, the addition of control kareish cheese PKA to pate led to record the highest total score among all treatments (97 out of 100). While treatment PKD occupied the second rank at total score (96 out of $100)$, followed by treatment $\mathrm{PKB}$, which recorded total score (92 out of 100), then treatment PKE achieved total score (86 out of 100). Treatment PKC occupied the last rank with the lowest total score (84 out of 100).

TABLE 1. Nutritional value of fresh kareish cheese treatments.

\begin{tabular}{|c|c|c|c|c|c|c|}
\hline & & \multirow{2}{*}{$\begin{array}{c}\text { Without } \\
\text { additives } \\
1 \% \text { lima } \\
\text { bean flour }\end{array}$} & \multicolumn{4}{|c|}{ Kareish cheese with } \\
\hline & & & $\begin{array}{l}1 \% \text { sweet } \\
\text { lupin flour }\end{array}$ & $\begin{array}{l}1 \% \text { talbina } \\
\text { powder }\end{array}$ & $\begin{array}{c}1 \% \text { oat } \\
\text { flours }\end{array}$ & \\
\hline \multirow{5}{*}{ Chemical composition } & Moisture (\%) & 74.223 & 75.912 & 74.585 & 74.807 & 76.262 \\
\hline & Protein (\%) & 17.891 & 18.167 & 18.412 & 17.986 & 16.830 \\
\hline & Fat $(\%)$ & 1.082 & 1.167 & 1.780 & 1.171 & 1.494 \\
\hline & Fiber (\%) & ---- & 0.004 & 0.083 & 0.032 & 0.039 \\
\hline & $\operatorname{Ash}(\%)$ & 2.070 & 2.000 & 2.100 & 2.210 & 2.260 \\
\hline \multirow{4}{*}{ Mineral contents } & $\operatorname{Mg}(\mathbf{m g} / \mathbf{1 0 0 g})$ & 82.000 & 105.810 & 117.000 & 109.010 & 106.110 \\
\hline & K (mg/100g) & 1147.400 & 1252.030 & 1152.570 & 1164.000 & 1194.070 \\
\hline & $\mathrm{Fe}(\mathrm{mg} / 100 \mathrm{~g})$ & 8.210 & 9.950 & 9.950 & 10.030 & 10.520 \\
\hline & $\mathrm{Zn}(\mathrm{mg} / \mathbf{1 0 0 g})$ & 5.350 & 6.900 & 7.070 & 6.560 & 6.470 \\
\hline
\end{tabular}


TABLE 2. The total calories for fresh samples of kareish chesses (Kcals/15g)

\begin{tabular}{|ccccc}
\hline Treatments & & & Kcals/15g & \\
Control Kareish cheese & Protein & Fat & Carbohydrate & Energy \\
\cline { 2 - 5 } & 2.68 & 0.16 & 0.71 & 15.00 \\
Kareish cheese with 1\% lima bean flour & 2.72 & 0.17 & 0.41 & 14.05 \\
Kareish cheese with 1\% sweet lupin flour & 2.76 & 0.26 & 0.46 & 15.22 \\
kareish cheese with 1\% talbina powder & 2.69 & 0.17 & 0.57 & 14.57 \\
kareish cheese with 1\% oat flours & 2.52 & 0.22 & 0.45 & 13.86 \\
\hline
\end{tabular}

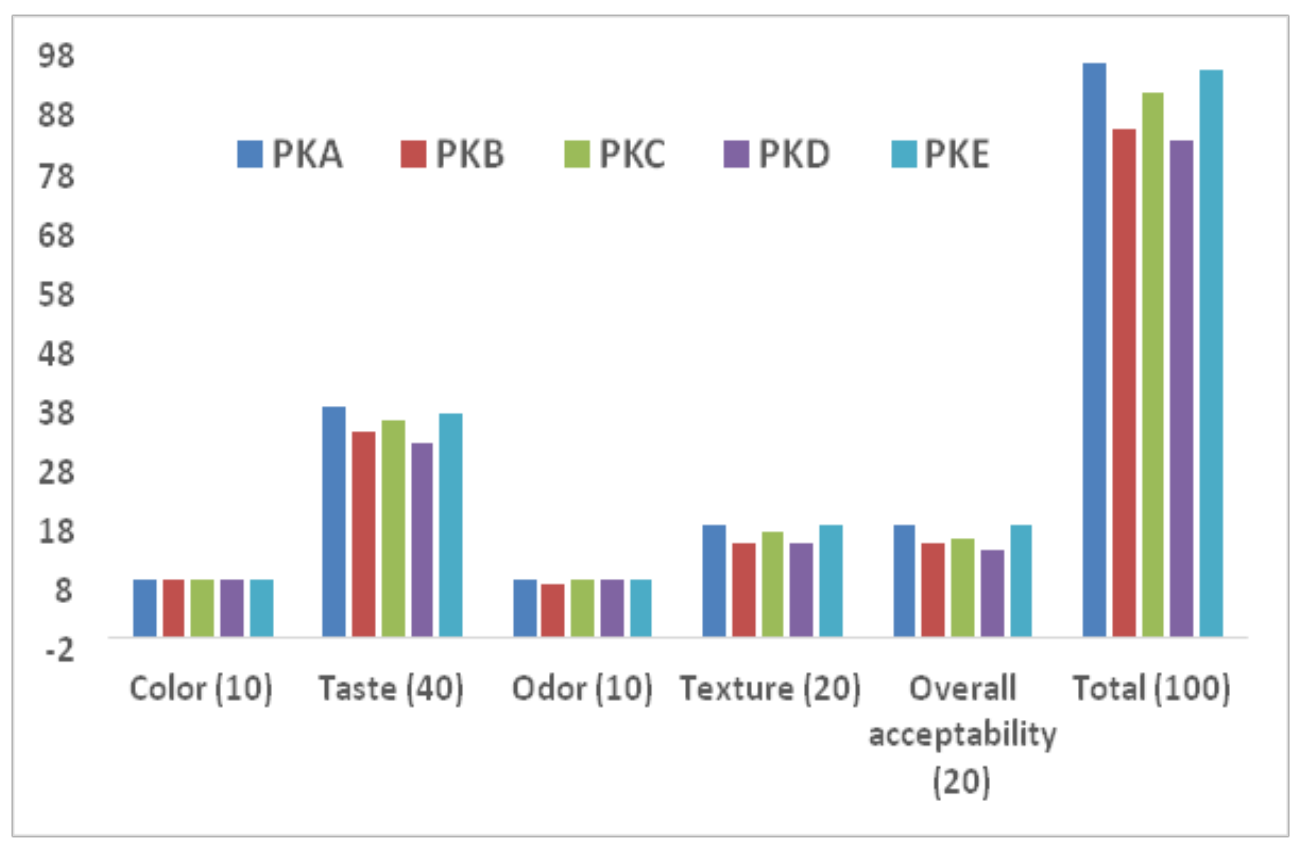

PKA: Pate stuffed with control kareish cheese; PKB: Pate stuffed with fortified kareish cheese with $1 \%$ lima bean flour; PKC: Pate stuffed with fortified kareish cheese with $1 \%$ sweet lupin flour; PKD:Pate stuffed with fortified kareish cheese with $1 \%$ talbina powder and PKE: Pate stuffed with fortified kareish cheese with $1 \%$ oat flour.

Fig. 1. Sensory Evaluation of pate stuffed with control and fortified kareish cheeses of $1 \%$ functional foods.

\section{2- Total calories for the pate products}

The total calories of the pate without fortified kareish cheeses was calculated and recorded total Energy, 1419.76 (Kcals/100g) (Table, 3). Those results similarly agreed with those mentioned by Akubor and Badifu (2004) and Méndez-Cid et al. (2007). The nearly equaled values had been reported by Jenkins and McGuire (2006) and Matt et al. (2009).

3- Total calories of pate stuffed with control and fortified kareish chesses with functional foods

Generally, it was noticed that PKC treatment recorded the highest total energy, 1434.98(Kcals/115g), followed with PKB, PKA, PKE and PKD treatments recorded total energy of $1433.81,1434.76,1433.62$ and 1434.33 (Kcals/115g), respectively.

Potatoes buriet with control and fortified kareish cheeses in ratio of $1 \%$ lima bean, sweet lupin, oat and talbina

\section{1- Sensory evaluation}

Treatment BKA recorded the highest total score (98 out of 100). Followed by treatment BKE recorded total score (96 out of 100). Treatment $\mathrm{BKC}$ came in the third rank with total score $(92$ out of 100). Then treatment BKB recorded total score (85 out of 100). Finally, treatment BKD recorded the lowest total score (81 out of 100) (Fig. 3). 
TABLE 3. Total calories for the pate products without fortified kareish cheese (Kcals/100g).

\begin{tabular}{cccccccc}
\hline \multirow{2}{*}{ Quantity } & Wheat flour & Whole milk & Butter & Egg & Sugar & Salt & \multirow{2}{*}{ Total } \\
\cline { 2 - 6 } & $500 \mathrm{~g}$ & $300 \mathrm{ml}$ & $450 \mathrm{~g}$ & $50 \mathrm{~g}$ & 3 (tbsp)* & 1 (tsp)** & \\
\hline Protein (g/100g) & 9.60 & 3.20 & 0.85 & 12.30 & -- & -- & 91.84 \\
Fat (g/100g) & 3.00 & 3.20 & 90.70 & 8.50 & -- & -- & 25.95 \\
Carbohydrate (g/100g) & 76.00 & 4.50 & 0.14 & 1.20 & 10.00 & -- & 105.40 \\
Energy (Kcals/100g) & 369.40 & 59.60 & 820.26 & 130.50 & 40.00 & -- & 1419.76 \\
\hline
\end{tabular}

*(tbsp): means tablespoon and per $(1 \mathrm{tbsp})=14.175 \mathrm{~g}$.

** (tsp): means teaspoon and per $(1 \mathrm{tsp})=4.725 \mathrm{~g}$.

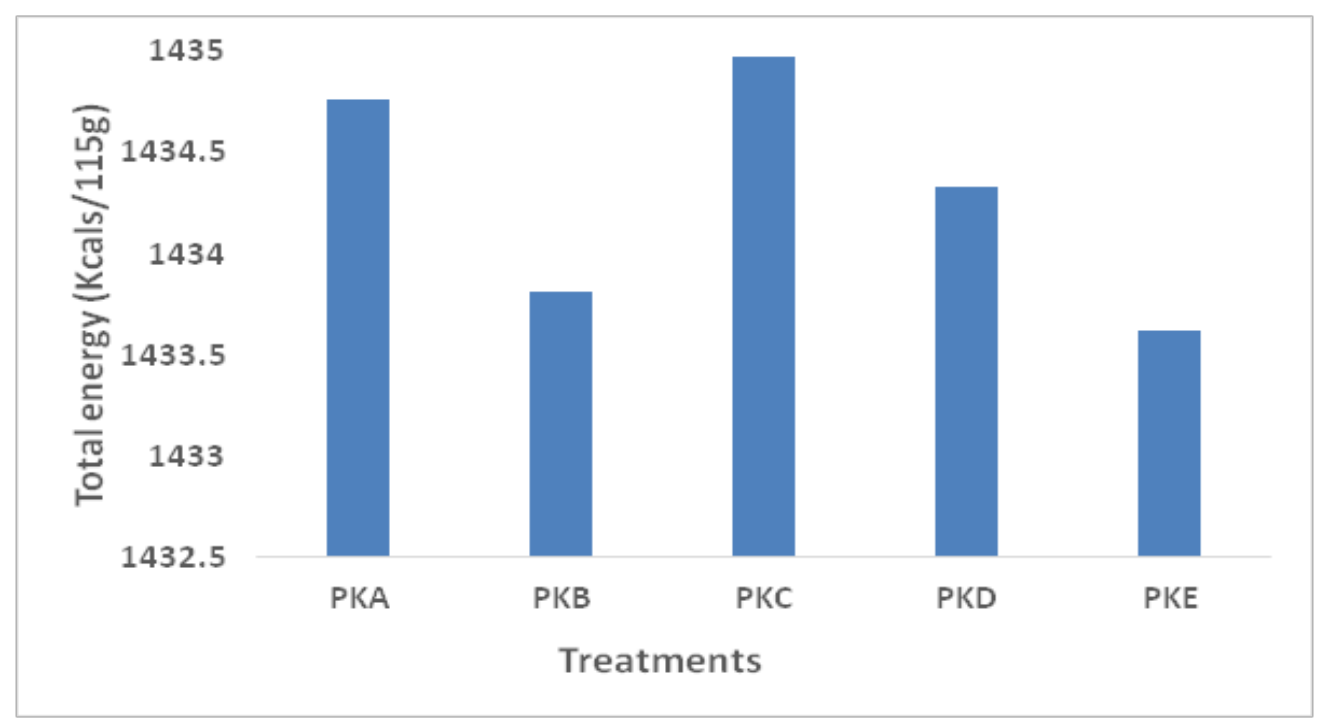

PKA: pate stuffed with control kareish cheese; PKB: pate stuffed with fortified kareish cheese with 1\% lima bean flour; PKC: pate stuffed with fortified kareish cheese with $1 \%$ sweet lupin flour; PKD: pate stuffed with fortified kareish cheese with $1 \%$ talbina powder and PKE: pate stuffed with fortified kareish cheese with $1 \%$ oat flour.

Fig.2.Total calories of pate stuffed with control and fortified kareish chesses with functional foods.

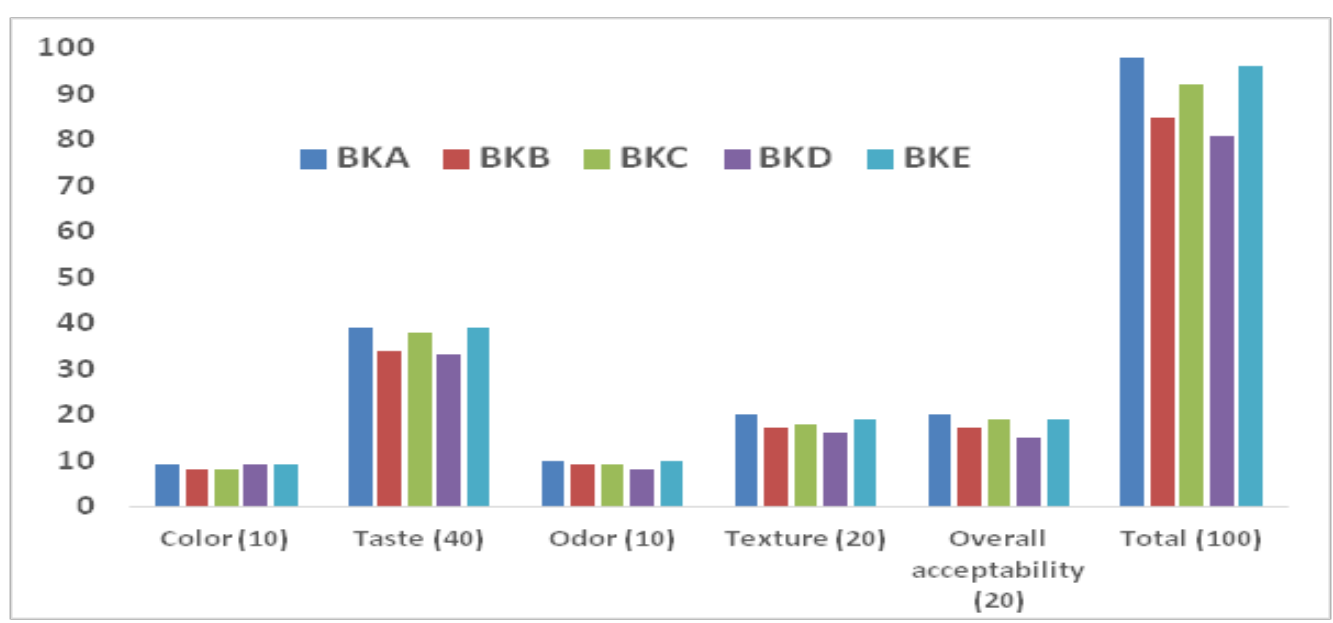

BKA: potatoes buriet fortified with $15 \%$ control kareish cheese; BKB: potatoes buriet with $15 \%$ fortified kareish cheese with $1 \%$ oat flour; BKC: potatoes buriet with $15 \%$ fortified kareish cheese with $1 \%$ lima bean flour; BKD: potatoes buriet with $15 \%$ fortified kareish cheese with $1 \%$ sweet lupin powder and BKE: potatoes buriet with $15 \%$ fortified kareish cheese with $1 \%$ talbina powder.

Fig. 3. Sensory Evaluation of potatoes buriet with fresh fortified kareish cheeses with $1 \%$ functional foods.

Egypt. J. Food Sci. 48, No. 2 (2020) 
2- Total calories for the potatoes buriet products: The total calories of the potatoes buriet without fortified kareish cheeses was calculated and recorded total Energy, 947.65 (Kcals/100g). It was obvious that white potatoes determined $(1.30 \mathrm{~g} / 100 \mathrm{~g})$ for protein, $(0.91 \mathrm{~g} / 100 \mathrm{~g})$ for fat and $(13.40 \mathrm{~g} / 100 \mathrm{~g})$ for carbohydrate and those values were agreeing with Hätönen et al. (2011). And recorded energy, 67.79 (Kcals/100g). Moreover, whole milk achieved $(3.20 \mathrm{~g} / 100 \mathrm{~g})$ protein, $(3.20 \mathrm{~g} / 100 \mathrm{~g})$ fat and $(4.50 \mathrm{~g} / 100 \mathrm{~g})$ carbohydrates. The nearly equaled values had been reported by Jenkins and McGuire (2006). And obtained energy, 59.60 (Kcals/100g). In addition, butter obtained $(0.85 \mathrm{~g} / 100 \mathrm{~g})$ for protein, $(90.70 \mathrm{~g} / 100 \mathrm{~g})$ for fat and $(0.14 \mathrm{~g} / 100 \mathrm{~g})$ for carbohydrates and those results agreed with those obtained according to Méndez-Cid et al. (2007)and gained energy, 820.26 (Kcals/100g).
3- Total calories of potatoes buriet stuffed with control and fortified kareish chesses with functional foods: Total calories of potatoes buriet with control and fortified kareish chesses were calculated based on total energy of potatoes buriet (Kcals/100g), which calculated and mentioned in (Table, 4 ) and total calories of $15 \%$ control/fortified kareish cheeses (Kcals/15g) which calculated in Table (2). Generally, it was noticed that BKD treatment recorded the highest total energy, 962.87 (Kcals/115g), followed with BKA treatment gained energy, 962.6 (Kcals/115g). Then BKE treatmentrecordedthe total energy, 962.22 (Kcals/115g). After that BKCtreatment achieved energy, 961.70 (Kcals/115g). While,BKBtreatment occupied the last rank at 961.51 (Kcals/115g) (Fig. 4).

TABLE 4. Total calories for the potatoes buriet products (Kcals/100g).

\begin{tabular}{cccccc}
\hline Quantity & White Potato & Whole milk & Butter & Spices & Total \\
& $300 \mathrm{~g}$ & $15 \mathrm{~mL}$ & $30 \mathrm{~g}$ & 3 (tbsp)* & \\
\hline Protein (g/100g) & 1.30 & 3.20 & 0.85 & - & $\mathbf{1 8 . 2 4}$ \\
Fat (g/100g) & 0.91 & 3.20 & 90.70 & -- & $\mathbf{5 . 4 5}$ \\
Carbohydrate (g/100g) & 13.40 & 4.50 & 0.14 & -- & $\mathbf{9 4 . 8 1}$ \\
Energy (Kcals/100g) & 67.79 & 59.60 & 820.26 & -- & $\mathbf{9 4 7 . 6 5}$ \\
\hline
\end{tabular}

*(tsp): means teaspoon and per $(1 \mathrm{tsp})=4.725 \mathrm{~g}$.

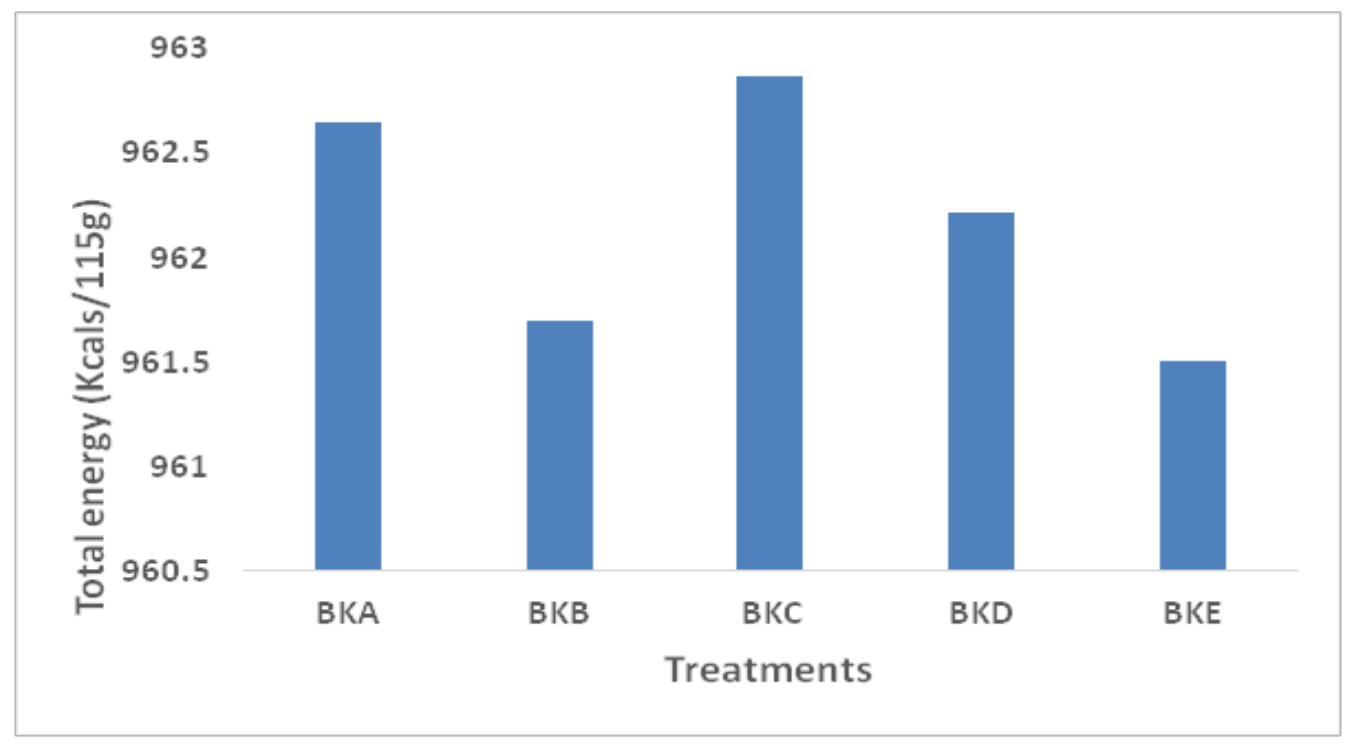

BKA: potatoes buriet fortified with $15 \%$ kareish cheese without any additive; BKB: potatoes buriet with $15 \%$ fortified kareish cheese with $1 \%$ oat flour; BKC: potatoes buriet with 15\% fortified kareish cheese with $1 \%$ lima bean flour; BKD: potatoes buriet with $15 \%$ fortified kareish cheese with $1 \%$ sweet lupin powder and BKE: potatoes buriet with $15 \%$ fortified kareish cheese with $1 \%$ talbina powder.

Fig. 4. Total calories of potatoes buriet stuffed with control and fortified kareish chesses with functional foods. 


\section{Conclusion}

Sensory evaluation was carried out and the results presented that pate and potatoes buriet which added to them about $15 \%$ of control kareish cheese was the highest acceptance, followed by those added to them kareish cheese fortified with talbina, followed by those added to them kareish cheese fortified with lima bean, then followed by those added to them kareish cheese fortified with oat, then followed by those added to them kareish cheese fortified with sweet lupin. Total calories were calculated, it was found that pate and potatoes buriet which added to them about $15 \%$ (W/W) of kareish cheese fortified with sweet lupin were the highest calories, followed by the kareish cheese control, then followed by the kareish cheese fortified with talbina, then followed by the kareish cheese fortified with lima bean, then followed by kareish cheese fortified with oat.

\section{References}

Akubor, P.I. and Badifu, G.I. (2004) Chemical composition, functional properties and baking potential of African breadfruit kernel and wheat flour blends. Inter. J. Food Sci. \& Tech., 39 (2), 223-229. https://doi.org/10.1046/j.09505423.2003.00768.x

AOAC (Association of official Agriculture Chemists) (2012) Official Methods of Official Analysis Chemists. $19^{\text {th }}$ ed. William Hornitz, (Ed) pub Association of official Agric. Chemists, Washington, DC, USA. https://doi.org/10.5962/ bhl.title.44636

APHA (2005) (American Public Health Association). Standard methods for the examination of water and wastewater: Washington, DC, USA. https://doi. org/10.4135/9781412950602.n35

Awad, R.A., Salama, W.M. and Farahat, A.M. (2014) Effect of lupine as cheese base substitution on technological and nutritional properties of processed cheese analogue. Acta Scientiarum Polonorum Technologia Alimentaria, 13 (1), 5564. https://doi.org/10.17306/j.afs.2014.1.5

Bawazir, A.E. (2012) Effect of chocolate brown HT with olive oil on some neurotransmitters in different brain regions, physiological and histological structure of liver and kidney of male albino rats. Journal of Evolutionary Biology Research, 4 (1), 13-23. https://doi.org/10.5897/jebr12.001

Christian, M. P., C. Grainger, Suttherland, B. J., Mayes, J. J., Hannah, M. C. and Kefford, B.
(1999) Managing diet quality for Cheddar cheese manufacturing milk. 1 . The influence of protein and energy supplements. J. Dairy Res., 66 (3), 341-355. https://doi.org/10.1017/s0022029999003647

CoStat program, Version 6.311 (2005) CoHort Software, 798 Lighthouse Ave PMB 320, Monterey. CA, 3940USA. http://www.cohort.com

Effat, B.A., Salem, M.M.E. and El-Shafei, K. (2001) Effect of using different starters on quality of Kareish cheese [Egyptian soft cheese]. Egyptian J. Food Sci. (Egypt), 29, 95-108. https://agris.fao.org/ agris-search/search.do?recordID=EG2002000715

Eisner, P., Muller, K., Knauf, U. and Kloth, G. (2008) US Patent Application, Reports of Patent, Design and Trade Mark Cases, No. 121(11), 413. https://doi.org/10.1093/rpc/2004rpc20

El-Nemr, T.M., Awad, S.A., Bisar, G., Jjuuko, J.R. (2007) Utilization of raffinose family of oligosaccharides from sweet lupin (Lupinus termis) as a prebiotic into karish cheese analog. $10^{\text {th }}$ Egyptian Conference for Dairy Science and Technology, Research Papers, held at The International Agriculture Centre, Cairo, Egypt, Egyptian Society of Dairy Science,19-21 Nov., (377-390) ref. 41. https://www.cabdirect.org/ cabdirect/abstract/20083078746

Elsamani, M.O., Habbani, S.S., Babiker, E.E. and Ahmed, I.A.M. (2014)Biochemical, microbial and sensory evaluation of white soft cheese made from cow and lupin milk. LWT-Food Sci. \& Tech., 59(1), 553-559. https://doi.org/10.1016/j.lwt.2014.04.027

Fayed, A.E., Farahat, A.M., Metwally, A.E. and Emam, M.S. (2014) Health stimulating properties of the most popular soft cheese in Egypt Kariesh made using skimmed milk UF-retentate and probiotics. Acta Scientiarum Polonorum Technologia Alimentaria, 13 (4), 359-373. https:// doi.org/10.17306/j.afs.2014.4.3

El-Shafei, K., Abd El-Gawad, M.A., Dabiza, N., Sharaf, O.M. and Effat, B.A. (2008) A mixed culture of Propionibacterium thoenii P-127, Lactobacillus rhamnosus and Lactobacillus plantarum as protective cultures in Kareish cheese. Polish J. Food and Nutr. Sci., 58 (4), 433-441. http://yadda. icm.edu.pl/yadda/element/bwmeta1.element.agroa2529da1-e645-41d2-8ab6-544d95c96bbd

Gassenmeier, K., and Schieberle, P. (1994) Comparison of important odorants in puff-pastries prepared with butter or margarine. LWT-Food Sci. \& Tech., 27 (3), 282-288. https://doi.org/10.1006/fstl.1994.1056 
Ghada, Z.A.A., Alia, M.H., Soha, Al-S., Magdy, N.A. and Mohammed, F.S.(2004) Chemical, Nutritional and Microbiological Evaluation of some Egyptian Soft Cheeses. The Egyptian Journal of Hospital Medicine, 17, 44-57. https://ejhm.journals.ekb. eg/article_18155_8a11f67fdc86bc0ffda062aa8 6e93645.pdf

Hassan and Bello (1988) An investigation of accelerated water-uptake in dry pea beans Res Progress Rept., 211 Indian Agric Express Station, West Lafayette.

Hathout, A.S. and Aly, S.E. (2010)Role of lactic acid bacteria as a biopreservative agent of Talbina. J. American Sci., 6 (12), 889-898. http:// www.jofamericanscience.org/journals/am-sci/ am0612/98_4219am0612_889_898.pdf

Hätönen, K. A., Virtamo, J., Eriksson, J.G., Sinkko, H.K., Sundvall, J.E. and Valsta, L.M. (2011) Protein and fat modify the glycaemic and insulinaemic responses to a mashed potato-based meal. British J. nutr., 106 (2), 248-253. https://doi.org/10.1017/ s0007114511000080

Jenkins, T.C. and McGuire, M.A.(2006) Major advances in nutrition: impact on milk composition. J. Dairy Sci., 89 (4), 1302-1310._https://doi.org/10.3168/jds. s0022-0302(06)72198-1

Jensen, M.K., Koh-Banerjee, P., Franz, M., Sampson, L., Grønbæk, M. and Rimm, E.B. (2006) Whole grains, bran, and germ in relation to homocysteine and markers of glycemic control, lipids, and inflammation. The American journal of clinical nutrition, 83 (2), 275-283. https://doi.org/10.1093/ ajcn/83.2.275

Kohajdova, Z., KaroVičoVá, J. and Schmidt, S. (2011) Lupin composition and possible use in bakery-a review. Czech J. Food Sci., 29 (3), 203211. https://doi.org/10.17221/252/2009-cjfs

Kouris-Blazos, A. and R. Belski (2016)Health benefits of legumes and pulses with a focus on Australian sweet lupins. Asia Pacific journal of clinical nutrition. 25 (1), 1-17. DOI:10.6133/apjen.2016.25.1.23

Levent, H. and BilgiÇli, N. (2011) Enrichment of glutenfree cakes with lupin (lupin albus L.) or buckwheat (fagopyrum esculentum M.) flours. International Journal of food and nutritions, 62 (7), 725-728. https://doi.org/10.3109/09637486.2011.572546

Livesey, G. (1995) Metabolizable energy of macronutrients. American J. clinic. nutr., 62 (5), 1135S-1142S. https://doi.org/10.1093/ ajen/62.5.1135s

Matt, D., Veromann, E. and Luik, A. (2009) Effect of housing systems on biochemical composition of chicken eggs. Agronomy Research, 7 (II), 662-667. https://agronomy.emu.ee/vol07Spec2/p7sII15.pdf

Méndez-Cid, F.J., Centeno, J.A., Martínez, S. and Carballo, J. (2017) Changes in the chemical and physical characteristics of cow's milk butter during storage: Effects of temperature and addition of salt. J. Food Comp. \& Analysis, 63, 121-132. https://doi.org/10.1016/j.jfca.2017.07.032

Osman, O., Ozturk, I., Bayram, O., Kesmen, Z. and Yilmaz, M.T. (2010) Characterization of cheese Spoiling Yeasts and their Inhibition by Some Spices. Egypt. J. Dairy Sci.,75 (2): 637-640. https://doi.org/10.1111/j.1750-3841.2010.01871.x

Snowden, J., Sipsas, S. and John, C.S. (2007) US Patent Application No. 10 (554), 664. https://doi. org/10.1016/j.wpi.2006.10.007

Swapna, K.S. and Rao, K.J. (2016) Studies on effect of oat and cheese incorporation on sensory and textural quality of short-dough type biscuit. Journal of food science and technology, 53 (3), 1505-1514. https://doi.org/10.1007/s13197-015-2014-x

Watts, B.M., Ylimaki, G.L., Jeffery, L.E. and Elias, L.G. (1989)Basic Sensory Methods for Food Evaluation. Inter. Development Res. Center, Ottawa, 60-63. https://www.scirp.org/ (S(czeh2tfqyw2orz553k1w0r45))/reference/ ReferencesPapers.aspx?ReferenceID $=1753372$

Weightman, R.M., Heywood, C. Wade, A. and South, J.B.(2004)Relationship between grain $(1 \rightarrow 3,1 \rightarrow$ $4)$ - $\beta$-d-glucan concentration and the response of winter-sown oats to contrasting forms of applied nitrogen. J. cereal sci., 40 (1), 81-86. https://doi. org/10.1016/j.jcs.2004.04.006

Xue, X., Wang, J., Li, S., Zhang, X., Dong, J., Gui, L., and Chang, Q (2020)Effect of micronised oat bran by ultrafine grinding on dietary fibre, texture and rheological characteristic of soft cheese. Inter. $J$. Food Sci. \& Techn., 55 (2), 578-588. https://doi. org/10.1111/ijfs.14309

Yellavila S.B., Agbenorhevi, J.K., Asibuo, J.Y. and Sampson, G.O. (2015)Proximate composition, minerals content and functional properties of five Lima bean accessions. J. Food Sec., 3, 69-74. http://pubs.sciepub.com/jfs/3/3/1

Yorgancilar, M., Atalay, E. and Babaoglu, M. (2009) Aciligi giderilmiş termiye tohumlarinin (lupen = lupinus albus 1.) mineral iÇerigi. SelÇuk, J. Agric Food Sci. 23 (50), 10-15 (in Turkish), https:// www.semanticscholar.org/paper/ACILI\%C4\%9EI-

Egypt. J. Food Sci. 48, No. 2 (2020) 